\title{
Understanding The Mad Heart: A Deconstructionist Approach To Efua T. Sutherland's Edufa
}

\author{
Lucy Korkoi Bonku, Confidence Gbolo Sanka*, Philomena Yeboah
}

${ }^{1}$ Department of Liberal Studies, Kumasi Technical University, Ghana, ${ }^{2}$ Department of English, Kwame Nkrumah University of Science and Technology (KNUST) Kumasi, Ghana

Corresponding Author: Confidence Gbolo Sanka, E-mail: fikoff75@gmail.com

\section{ARTICLE INFO}

Article history

Received: December 19, 2017

Accepted: March 14, 2018

Published: April 30, 2018

Volume: 9 Issue: 2

Advance access: March 2018

Conflicts of interest: None

Funding: None

\section{Key words:}

Deconstruction,

Ghana,

Love,

Language,

Marriage,

Mythopoesis,

Patriarchy.

\begin{abstract}
Myths constitute an important part of human development. Life enduring values are embedded in these myths and the adaptation of some of these archetypal myths from culture to culture ensures shared virtues and opinions on human experience. This paper investigates, using the theories of myth and deconstruction, the relationship between Euripedes' Alcestis myth and the Edufa myth written by Afua Sutherland. A comparative analysis of the two myths indicates that Sutherland adapted the Greek myth to the Ghanaian context. However, due to the fluid and unstable nature of language and meaning in general and due to same qualities of the discourse in $E d u f a$, a deconstructionist approach has been used in this paper to derive a powerful message on the responsibility of the mother cum wife. The findings reveal that Sutherland does not endorse the kind of love exhibited by Ampoma; rather, she proscribes it. The dramatist's adept use of language and the text's leaning on lessons from the African concept of marriage is what makes this deconstructionist's reading possible.
\end{abstract}

\section{INTRODUCTION}

Myths are stories that are "regarded as fictional stories containing deeper truths, expressing collective attitudes to fundamental matters of life, death, divinity and existence" (Baldick 174). Humanity all over the world is attracted to myths because they are believed to contain deeper truths about life and also because they generally discuss issues that are fundamental to man. Myths can be adapted and created, through mythopoesis, to suit the needs and requirements of various societies. On the other hand, deconstructionist criticism examines the ways in which language is a "fluid, ambiguous domain of complex experience" and how this fluidity empowers language to "disseminate an infinite number of possible meanings"(Tyson 249, 256).

In the myth of Edufa, Ampoma is presented, apparently, as a wife who is prepared, unconditionally, to lay down her life for that of her husband. This is the meaning that is derived from the surface phenomena of the text. Indeed, readers and theatre-goers wonder about the kind of heart that will condition a wife/mother to live a life of self-effacing sacrifice while abnegating her core responsibilities towards her children and husband. It is this disturbing issue which has subsumed the angst of the paper and thrust the researchers into finding satisfactory answers to it. However, a deconstructionist interpretation of the play reveals Ampoma as a Ghanaian wife who lacks a thorough understanding of love in the African context and her role and responsibilities in a marriage. Such a lacuna in the understanding of her obligations towards her children and husband lands the entire family in jeopardy. This self-inflicted death and oppression in the name of "love" is what Sutherland wants other women from Ghana and Africa to avoid.

\section{METHODOLOGY AND LITERATURE REVIEW}

Edufa and Euripedes' Alcestis are the sources from which primary data has been obtained for the analysis of issues raised in this paper. Secondary data which consist of the review of documented sources on deconstruction, mythopoesis and marriage have also been used to bolster arguments in the paper. The paper itself is divided into four main parts: introduction, methodology and literature, analysis of the two myths on the basis of mythopoesis and deconstruction, and a conclusion. 
Africa, as in other societies, is replete with varied myths which seek to explain certain natural phenomena as well as incorporate codes of morality and conduct. Historically, myths have had a tremendous fascination for Africans who imbibe them because they attach a kind of reverence to these myths. The belief is that myths, due to their mysterious and sacred nature, are imbued with some true values which are expected to "be accepted on faith" (Finnegan 362). There are various kinds of myths which seek to explain natural phenomena and these are referred to as creation myths. Analogical myths are those myths which provide explanations about human origin. Myths of origin can be sandwiched between creation and analogical myths because they explain the beginning of specific societies. Added to this list also are fictional myths which are common to many societies. These fictional myths tell stories which are usually moralistic and didactic.

Efua Sutherland's Edufa is an example of a fictional myth which incorporates a gender myth. Gender myths are myths which seek to project both positive and negative values about men and women. Within the corpus of gender myths, we can identify those that facilitate women's empowerment and also those that project negative behavioral patterns such as jealousy, unreliability, rivalry, idealistic love, rush judgment, baseless egalitarianism and so on. Put together, the aforementioned categories of myths play strategic roles in transmitting values and ensuring discipline, whilst at the same time enhancing our appreciation of human civilisation and shaping our understanding of gender roles and socialisation. A woman's place in the home and society is, to a large extent, shaped especially by myths and many of the gender constructions are derived from mythic transmissions from one generation to another. An evaluation of gender myths is a credible exercise in understanding, reviewing and revising unacceptable proliferation of negative feminine images without making recourse to any ideological jacket.

In Africa, myths have the propensity to shape lives and values. This angle of reading Sutherland's Edufa reveals that through this play, Sutherland is discouraging all forms of idealism in marriage. It teaches lessons about rush decisions and directs the focus of a wife and mother's first love. Should a mother/wife value the welfare of her children above an idealised love affair? This question is not only answered but is also dramatised by Sutherland in Edufa.

Kolawole advances the view that African myths provide reasons for certain unexplained behavioral patterns and occurrences. African myths are, to a very large extent, paradigms that explain the reasons for the status quo and explicate the origin of certain actions, values or social patterns. Indeed, Kolawole observes that "African literature, philosophy, religion and arts incorporate myths of gender that have tremendous influence on women's self-esteem" (54).

Kolawole's assertion creates levels of understanding of the adaptation of the Alcestis myth by Sutherland in Edufa. The choice of this myth by Sutherland then can be understood based on Kolawole's observation that in the African context, mythology plays a central role in transmitting values and instilling discipline. It enhances the understanding of human civilisation and shapes gender roles and sociali- sation. Levi Strauss observes that myth often influences and shapes imagination unconsciously since it "operates without our knowledge"(quoted in Jackson 22). This explains why Sutherland adapts relevant parts of the Alcestis myth and plants them on a blossoming African stage to enable her shape the character of her shared gender. Molefi Kete Asante adds to this discourse by observing that myths constitute "a productive force". He emphasises that; "...myth becomes an explanation for the human condition and an answer to the problem of psychological existence in a recent society" (56).

This agrees with Kolawole and Levi-Strauss' shared view that myths are imbued with values. Helen Chukwuma's definition of myth is also apt since it seeks primarily to position the relevance of myth in African societies. According to her, myth is "a stabilizer of social system, a reflector of value systems, a means of recreating past history or a psychoanalytical insight into human behavior motivation"(100). We then understand why some women will elect to parade an idealistic love and cast a backward glance on their core role of protecting and keeping the lives of their vulnerable children safe.

The reason for Sutherland's adaptation of the Alcestis myth is sourced from the fact that many a mythic imagination is imbued with the potential of structuring human thought and actions. Sutherland's Edufa dramatises a romantic love between a couple that results in the tragic death of the wife whose irresponsible display of love for her husband blinds her to the realities of the materialistic machinations and manipulations of her husband.

This paper which is based on a critical deconstructionist analysis of Sutherland's Edufa, which borrows heavily from the plot of Euripedes' Alcestis provides a credible exercise that helps questions some of the weaknesses in women that are sometimes perceived wrongly as strength. The story of Ampoma in Sutherland's Edufa, though imbued with remarkable display of love, reveals some ambivalence which demands a second look in order to interrogate and to reveal Ampoma's own role in her calamity. The Alcestis story and the play Edufa have been reviewed to assess how far these assertions are true.

\section{ANALYSIS}

Written by Euripedes around 484-406BCE, the Alcestis play has it that Alcestis was the beautiful daughter of Pelias, King of Iolcus (of Greece). When she was of age, many suitors appeared before her father, King Pelias, to seek the hand of his daughter Alcestis in marriage. Pelias then declared that his daughter would marry the first man to be able to yoke a lion and a boar to a chariot. King Admentus, determined to do this, sought the help of the god Apollo, who had been banished from Olympus for nine years to serve as a shepherd to Admentus. With Apollo's help, Admentus was able to complete the king's task and hence was allowed to marry Alcestis. Admentus forgot to make the required sacrifice of appreciation to the god Artemis after the wedding and found his bed full of snakes. Bitten by the snakes and about to die, Apollo again helped King Admentus by persuading the Fates, the goddesses who determine human destiny, to pro- 
long his life. The Fates declared that if anyone would want to die instead of Admentus they would allow it. Since no one volunteered, not even Admentus' elderly parents, his loyal wife, Alcestis, offered to die. Shortly after, Heracles, the warrior rescued Alcestis from Hades (the land of the dead) as a token of appreciation for the hospitality of Admentus.

Edufa, the protagonist in the play Edufa was an extremely wealthy man whose earnest desire was to keep and enjoy his wealth as well as his life for as long as possible. He consulted a diviner who revealed that death was looming over him and he would not live long. To avoid this death, someone had to swear over a powerful charm to die on his behalf. This was the only way to avert the looming death for Edufa to enjoy his life. Edufa, tactically asked who was willing enough to die on his behalf to which Ampoma, his wife, agreed to do. Later, Ampoma died, leaving Edufa with immense guilt and he eventually became mentally deranged.

The play Edufa and the myth Alcestis have certain features which link them yet the myth has some dissimilarities as well with the play Edufa. Sutherland's Edufa borrows heavily from Euripedes' Alcestis (484-406BCE). It must, however, be stated that though Sutherland borrows from this myth, she is selective as she makes strategic minuses of the Alcestis story whilst at the same time, adding some aspects to her own version. This really showcases an exercise in reaccentuating or mythopoesis where a renewed emphasis is placed on an old subject. By being selective in her adaptation of the Alcestis story, Sutherland is restructuring the emphasis of the story in line with a particular moral lesson she is determined to share with her readership.

In both stories, the two women demonstrated the depth of love they had for their husbands and exchanged their lives for their husbands as a classical show of their love towards them. In the case of Alcestis, she knew the fate of Admentus yet she willingly decided to give up her life in order for him to live. Ampoma's case is rather different; she was no privy to the knowledge of the danger of the charm in Edufa's hand. It can thus be said that in Ampoma's case there is a huge sense of deception on the part of her husband, Edufa. This is proven by Sutherland's apt description of Edufa's posture as he solicited from his family who it was that wanted to die in his stead.

One of the most classical uses of oxymoron is displayed by Efua Sutherland as she succinctly captures the exact picture of Edufa's deception. In Act I Scene 4, Kankam describes Edufa's tactical ambush on Ampoma's naïve psyche:

How could we have known it was not a joke, when you suddenly leaned back and asked which of us loved you well enough to die for you, throwing the question into the air with studied carelessness? Emaciated one, how could we have known of your treachery? (Sutherland 111)

The use of the rhetorical question in Kankam's speech depicts his sarcasm and points to condemnation. This is seen as an instance of domestic tribunal in which a son stands trial before his own father and gets condemned. This condemnation of Edufa's act of deception comes out forcefully by his use of the oxymoron 'studied carelessness'. Two opposite words are placed side-by-side yet they hold so much power in that, it clearly depicts a high level of deception. As though he was being careless, his own intellect was not only agile and analytical enough but also intimidating. It is no wonder then that the naïve Ampomah fell prey to this web of deception and proclaimed the words of love that finally resulted in her death. Kankam captures Ampoma's innocence by elevating his maturity above Ampoma's naivety. Kankam acquiesces:

You had willed that some old wheezer like me should be the victim. And Iwas the first to speak, 'Not me, my son,'said I jokingly. 'Die your own death.I have mine to die.' And we all laughed.Do you remember? My age was protecting me. Then Ampoma spoke. Yes I see you wince in the same manner as you did when she spoke the fatal words that day and condemned her life. 'I will die for you Edufa,' she said; and meant it too, poor, doting woman. (Sutherland 111)

Kankam's choice of words demands some attention. Though he talks about joking when he replied, 'die your own death, I have mine to die,' it was really not a joke; it was actually a serious assertion he made and Kankam himself was so much aware of the seriousness of the oath. Thus, his reference to his words as a joke is an exercise in sarcasm meant to taunt Edufa's limited view of the stretch of his father's wisdom. Kankam points to Edufa that whereas he applied nonverbal tactics, he also applied nonverbal analysis in reading Edufa's gestures: "Yes, I see you wince in the same manner as you did when she spoke the fatal words that day and condemned her life" (Sutherland 111) The verb 'wince' is calculated to condemn Edufa the more for by wincing, he demonstrates a full awareness of the danger within which his wife stood as she proclaimed the words "I will die for you, Edufa" (Sutherland 111).

Kankam then proceeds to give us the reason behind Ampoma's rather careless display of love. This reason, interestingly, is not captured in a long speech. Kankam uses just two words to describe Ampoma; "...poor, doting woman" (Sutherland 111). Short as they may seem, these two words carry within them our understanding of what it means for the heart of a woman, a wife and a mother to be described by the present researchers as a 'mad heart'. The mad heart is that heart which, when in love, displays sheer carelessness. The word 'poor' is used metaphorically by Kankam to point to Ampoma's naivity rather than lack of money or material comfort. Being naïve, Ampoma forgot that her voluntary wish to die for her husband would deprive her children of their mother who they need to survive in a ruthless world. She also forgot, temporarily, that her wishful death would pave the way for another woman to taste her husband's love. The word 'poor' as used by Kankam also communicates a display of stupidity and even selfishness. Stupidity because she turns a blind eye to the reality; that the very man she is swearing away her life for may bring in another woman immediately she is gone. In that case, what purpose would her death serve? It is thus a senseless death which will only pave the way for her husband to taste another woman's love. It sounds logical to describe Ampoma's declaration as selfish rather than selfless, when we consider that Ampoma is first and foremost a mother whose responsibility is to ensure that her children are properly nurtured and protected since they 
are younger and more vulnerable to the vagaries of life than her husband. In this context, it makes sense that by electing to die for her husband she was displaying an act of selfishness. She was obsessed with her willingness to display to her husband that she loves him too much. With this obsession, she ignored the welfare and survival of her children.

Oduyoye collaborates this view as she observes:

"It is recognized that the survival of the next generation is not limited to the availability of a mother's breastmilk. Mothers not only feed, but also protect the young. All the proverbial observations about hens and chickens also hold for the human community. The welfare of children takes precedence over everything else in a woman's life; nothing else is as important." (p.60)

Oduyoye's argument above explains our castigation of Ampoma's utterance as selfish in swearing away her life. It also explains our deconstruction of Ampoma's love as untenable in the world of the play and in the traditional Ghanaian marriage life. Ampoma is seen as a mother electing voluntarily to cease caring for her vulnerable children. Ampoma's attitude contradicts the African concept of marriage in which "...everyone becomes an actor or actress and not just a spectator" (Mbiti 133).

The song writer, William Cowper, asks in the third stanza of the song 'Hark my soul! It is the Lord' that: Can a woman's tender care cease towards the child she bears? Though the song writer provides an answer in the last but one line of this stanza; "Yes, she may "forgetful be", this answer should not be taken on its face value as though it is normal for a mother's tender care to cease towards the child she bears. It is abnormal, especially because a mortal's love towards his children is compared to God's unique love towards humanity. If the object of comparison were to be a human being then it would have been normal for a woman's love to cease towards her children. However, in this song, it is God's love that is being compared to the love of a mere mortal. The emphasis in this song is not that it is normal for a woman to cease to care for her children. The actual angst of this comparison is the transient nature of human love which is being compared to the permanent nature of God's love. A mother's love towards her children is supposed to be unquestionable because there is this natural cord that bonds a mother to her children. She goes through nine months of pregnancy; breastfeeds the child and even nurtures the child to adulthood. God does not physically give birth to a child or breastfeeds it; however, His eagle eyes watch over humanity and provide all our needs.

Therefore, Ampoma's utterance which resulted in her death is a shallow and selfish display of love. By electing to die for her husband, she was not only being inimical to her own life but to the life of her own children whose care should have been her prior responsibility. It is only a 'mad heart' that would ignore all these realities and stubbornly run into its own grave.

Though Ampoma is reported by Kankam to have wept bitterly when the truth of Edufa's deception is made clear to her, she still continues to display the characteristics of a 'mad heart'. In Act 3 Scene 2, Ampoma continues to display her love, irrespective of her knowledge that her husband has greedily and shamelessly sold out her soul. In the presence of the chorus of women gathered, Ampoma picks her waist beads from a miniature casket and bequeaths it as a final gift to her husband Edufa. She asserts: "waist beads, bearing the breath of my tenderness" (Sutherland 146).

In the Ghanaian culture, waist beads are worn by women for various reasons depending on the need of the user. Among these reasons may be for protection; beads can also be worn to ward off evil spirits. They can be worn as adornments of beauty, for fertility reasons (especially in the case of women who have protracted issues with childbirth or inability to give birth) and above all is the reason that most women wear beads to appeal sexually to a husband or lover (Vesta et al. 43-44). In the latter case, it is the sole preserve of the husband or lover who views such ornament exclusively for his pleasure. It therefore becomes an embarrassment when such an exclusive ornament is displayed in public by the user. This shameless display of love deconstructs its relevance and elicits the embarrassed response of the chorus of women. With popping eyes, amidst laughter they shout "Oh! Oh!'”(Sutherland 146).

In bringing out her waist beads and bequeathing it to her husband, Ampoma is not only embarrassing herself but the chorus also; a woman's waist beads are not to be displayed in public. They are for the exclusive use and pleasure of the husband. Ampoma personifies the waist beads as bearing the 'breadth of her tenderness'. The use of personification here is critical in that it reveals Ampoma's limited view of marriage. For her, marriage is just a union of a man and a woman in love. Later, she commands Edufa to "wear it proudly, this symbol of the union of our flesh" (Sutherland 147). By now, Ampoma should have known that this marriage has produced two children and so whatever happens to this marriage automatically affects the children. By electing to leave this marriage through death, she was not only leaving her husband but shirking her responsibility to her children. Being a woman with a 'mad heart,' she limited her view of marriage to only romance and this is symbolised by the importance she placed on waist beads. Her behaviour at this point is not only embarrassing but shocking as seen from the varied reactions of those around her.

The chorus laughs as their eyes pop up. Senchi who is beside himself exclaims "Great! Whew!" Edufa himself is described as being in a state of shock. These varied reactions are pointers to her madness and the unacceptability of her actions. This act is followed by her mysterious words: “...With it, I declare to earth and sky and water, and all things with which we shall soon be one, that I am slave to your flesh and happy so to be. Wear it proudly, this symbol of the union of our flesh" (Sutherland 146). For Ampoma, what constitutes fulfillment in marriage is romance and sex as proven by the lines above. But this constitutes a very myopic view about marriage. The union of flesh alone is not enough: there must equally be a union of purpose in life, in shared responsibilities, in openness towards each other and above all, a mutual expression of love towards each other.

The preceding analysis is important at two levels. First, it reveals a shift from the Alcestis myth which does not incorporate this scene. Alcestis never gave beads nor did she 
limit her marriage to romance and sex. It is interesting to note that Efua Sutherland is adding on to the Alcestis myth. This addition is calculated at using myth not only to caution but to deconstruct shallow love and teach values to women in marriage. It is an exercise in myth making for she adds on to the myth so that she can draw lessons from the myth for women.

Women in marriage are cautioned to take time to understand the holistic meaning of marriage; sex and romance are only a limited part of marriage especially when there are children. The morale is clear; if Ampoma had thought about her children, probably she would not have chosen to die so quickly. If she had stretched her imagination further to incorporate the love for her children in the scheme of things, she would have spared herself a senseless death.

Ampoma's careless display of love would have been understood if she had even tested Edufa's commitment in her marriage. In the Alcestis myth, Admentus had to yoke a boar and a lion to a chariot in order to win and marry Alcestis. By doing so, Admentus had shown a high level of commitment by putting his life on the line as proof to his father-in-law that he would readily die for Alcestis. This provides enough reason for readers to understand why Alcestis reciprocates this display of love by also choosing to die in Admentus' place. The fact that Sutherland takes off this portion in her rendition of the Alcestis myth in Edufa is important because it buttresses the earlier argument that Ampoma displays irresponsibility in electing to die for a man who is only interested in material wealth and fame.

In the Admentus/Alcestis relationship, the two of them equally put their lives on the line for each other. This shows that their marriage was enveloped in companionship. However, the Ampoma/Edufa marriage is characterized by a master-servant relationship. Ampoma herself asserts boldly that: "I am slave to your flesh and happy so to be" (Sutherland 146).Ampoma's words deserve criticism in that they showcase her flight into the patriarchal world. Rosemary Agonita has observed that marriage and patriarchy are bedfellows:

By nature, dominion is maternal for two reasons - the identity of a child's mother alone is certain, and power over a child is initially in the hands of a mother who nourishes and trains it. Marriage is the contract which brings about patriarchy. (p.97)

Agonita's observation points to a rather disturbing view. Is she alleging then that marriage automatically robs a woman of her rights? This rather pessimistic view from Agonita can be averted if, as subtly inferred from Sutherland's Edufa, women in marriage see themselves not only as slaves but as companions, as seen in the Alcestis and Admentus relationship. Probably it is some women who willingly or unwillingly become agents of patriarchy when they limit their view of marriage to a master/servant relationship.

Mercy Amba Oduyoye creates a different level of understanding of patriarchy by observing that: "Patriarchy exists whenever one finds systemic and normative inequalities and subordination"(131). From Oduoyoye's assertion, we could realize that patriarchy is not a biological occurrence between husband and wife; rather a woman who has a limited perception of marriage can elect to see herself as a subordinate.
Once that choice is made, she agrees to the terms of the patriarchal world.

In the Alcestis/Edufa myth the relevance of deities is revealed. Diviners soothe people's fears and this explains why people go to them. In Edufa the consultation of a diviner made Eudfa aware of the outcome of his life. The god, Apollo. we are told, helped Admentus win Alcestis as his wife and the Fates, the keepers of life and destiny were the ones consulted in order to find out how Admentus could keep his life. However, Edufa's visit to the diviner is not caused by ungratefulness to any supernatural being but a feeling of insecurity made him go to the shrine to find out his fortune. At the core of this feeling of insecurity is Edufa's fear of losing grasp of his wealth and fame. He tells this to Senchi:

Ask the town. They know who Edufa is and what he's worth. They can count you out my value in the homes that eat because I live. Yes my enterprises feed them. They rise in deference from their chairs when they say my name.If that isn't something, what is? And can a man allow himself to lose grip on that? Let it go? A position like that? You want to maintain it with substance, protect it from ever present envy with vigilance. And there's the strain that rips you apart! The pain of holding on to what you have. It gives birth to fears which pinch at the heart and dement the mind, until your needs must clutch at some other faith...Oh, it has driven me close to horror... and I tell you, I don't know what to think now. (Sutherland 132).

It is Edufa's greed and insatiable desire for recognition and fame which make him sacrifice the life of his wife. It is this same materialism which becomes the cause of his estrangement from his father Kankam and further breaks the bond between father and son.

Efua Sutherland, however, dismissed the power of materialism and fame and rather elevates love for human life. In an instance of poetic justice, Sutherland punishes Edufa by subjecting him to mental psychosis. As he wrenches himself free from Senchi's hands he is intent on snatching his wife from the grips of death. This is yet another departure from the Alcestis myth. Even though Alcestis is brought back to life, it is not done by human hands but by the supernatural hand of Apollo who does it as an act of appreciation for Admentus when he was banished from Olympus for nine years to serve as a shepherd to Admentus. Efua Sutherland's punishment of Edufa by making him reckless and mad also showcases a mortal's inability to fight death: "The last laugh will be mine when I bring her home again. I will bring Ampoma back. Forward to the grave. I will do it. I am conqueror! Conqueror...?”(Sutherland 153).

\section{CONCLUSION}

Sutherland's Edufa is an offshoot of Euripedes' Alcestis myth. There are a lot of parallels between the plots of the two plays. However, Sutherland also adapts her version of the myth to the Ghanaian and African context in order to raise pertinent questions about the role of a mother cum wife in a marriage. What kind of a heart will make Ampoma be- 
have the way she did in the play? It is only the mad heart of a woman in "love." Ampoma's actions are likely to be interpreted by many a reader as an endorsement of the "mad love" on the part of Sutherland. This is the position that this paper seeks to correct since a deconstructionist interpretation of the play reveals the opposite; Sutherland and the Ghanaian culture both proscribe irresponsible love. A lot of precautionary measures are taken during courtship and before marriage in Ghana and in Africa all because the society wants to ensure that responsible people are brought together in a marriage so as to guarantee the safe and proper upbringing of future generations; an irresponsible husband or wife is not only a guarantee of failure in the marriage but it is also a Pandora's box of all the problems that one can think of in life.

Sutherland's Edufa leads us to the inner motives and consequences of a woman's actions steeped in myth. Edu$f a$ creates levels of meaning as to why women as wives and mothers need to reason up in marriage. Taking for granted that a man loves you enough to die for you so that one, as a woman, can also die for him is naïve and dangerous not only to the woman but to the man as well. Perhaps if Ampoma had guarded her life so well, Edufa would not have ended up a mental case and her children would not have ended up motherless. Sutherland's Edufa which leans on the Alcestis myth is calculated at teaching morals and values to women as wives and mothers. It emphasises the need for women to protect their lives so that they can protect the lives of their children as well as the lives of their husbands.

\section{REFERENCES}

Jackson, R. L. (2004). African American communication \& identities: Essential readings. Sage.

Agonita, R. (1997). History of ideas on women: a source book. New York: Thomas Hobbes.

Asante, M.K. (1987). The Afrocentric idea. Philadelphia: Temple University Press.

Baldick, C. (2001). The concise oxford dictionary of literary terms. London: Oxford University Press.

Chukwuma, H. (1987). Ibo mythic schema. Critical Theory and African Literature, edited by Ernest Emeyonu, Ibadan: Heinemann.

Finnegan, R. (1976). Oral literature in Africa. Oxford: Oxford University Press.

Kolawole, M. (1997). Womanism and African consciousness. Trenton NJ: African World Press.

Mbiti, J.S. (1976). African philosophies and religions. London: Heinemann Educational Books Ltd.

Oduyoye, M. (1995) Daughters of Anowa: women and patriarchy. Maryknoll, NY: Orbis Book.

Sutherland, E. T.(1987). The Marriage of Anansewaa and Edufa. Harlow: Longman.,

Tyson, L. (2006). Critical theory today. Second Edition, New York: Routledge, Taylor and Francis Group.

Cowper, W. (1779). Hark my soul! It is the lord. Olney Hymns, Book 1, No. 118.

Vesta et al. (2015). The poetics of traditional Ghanaian beads. Global Journal of Human Social Science: Interdisciplinary, 15(2), 35-52. 